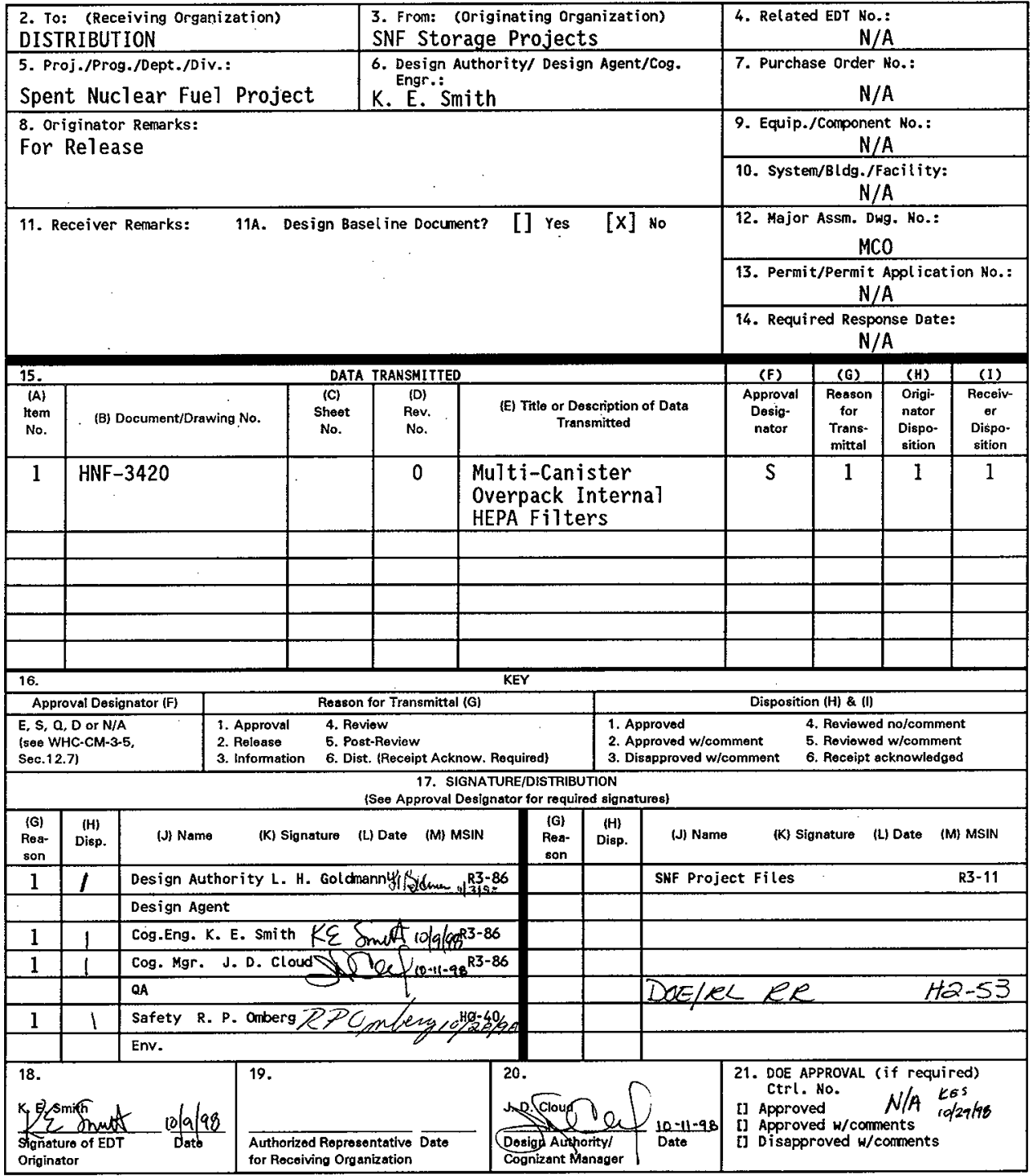




\title{
Multi-Canister Overpack Internal HEPA Filters
}

\author{
K. E. Smith
}

DE\&S Hanford, Inc., Richland, WA 99352

U.S. Department of Energy Contract DE-AC06-96RL13200

$\begin{array}{lll}\text { EDT/ECN: } & 625784 & \text { UC: } 600 \\ \text { Org Code: } & 2 \text { T340 } & \text { Charge Code: } 105532 / \text { AA30 } \\ \text { B\&R Code: } & \text { EW7040000 } & \text { Total Pages: } 5\end{array}$

Key Words: MCO, Spent Fuel, Packaging, Container, Issue, Filter, HEPA, Contamination

Abstract: The rationale for locating a filter assembly inside each Multi-Canister Overpack (MCO) rather than include the filter in the cold Vacuum Drying (CVD) process piping system was to el iminate the potential for contamination to the operators, processing equipment, and the MCO. The internal HEPA filters provide essential protection to facility workers from alpha contamination, both external skin contamination and potential internal depositions. Filters installed in the CVD process piping cannot mitigate potential contamination when breaking the process piping connections. Experience with K-Basin material has shown that even an extremely small release can result in personnel contamination and costly schedule distruptions to perform equipment and facility decontamination. Incorporating the filter function internal to the MCO rather than external is consistent with ALARA requirements of 10 CFR 835. Based on the above, the SNF Project position is to retain the internal HEPA filters in the MCO design.

TRADEMARK OISCLAIMER. Reference herein to any specific comercial product, process, or service by trade name, trademark, manufacturer, or otherwise, does not necessarily constitute or imply its endorsement, recommendation, or favoring by the United states Government or any agency thereof or its contractors or subcontractors.

Printed in the United States of America. To obtain copies of this document, contact: Document Control Services, P.0. Box 950, Mailstop H6-08, Richland WA 99352, Phone (509) 372-2420; Fax (509) 376-4989.
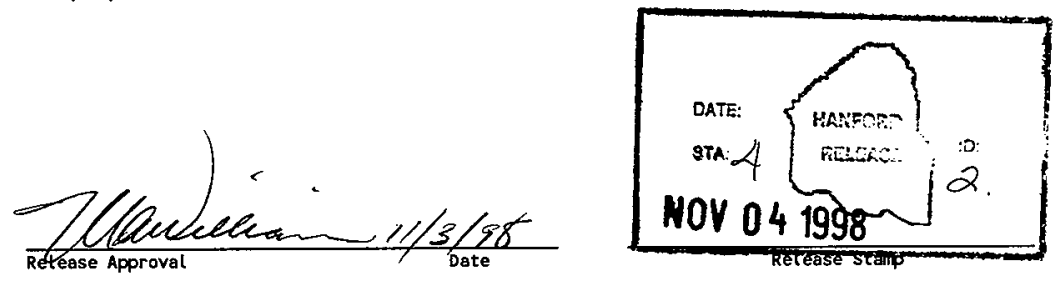

\section{Approved for Public Release}




\section{Issue Closure Package}

Issue: HCO Internal HEPA Filter

Lead:

K. E. Smith

$K \varepsilon$ smelt $10 / 9198$

MCO Implementation

Manager, DE\&S Hanford

\section{Approvals:}

Chief Engineer:

A. M. Segrest DE\&S Hanford

Technical Operations:

J. A. Swenson

Manager

DE\&S Hanford

Construction Projects:

A. R. Hollins

Manager

DE\&S Hanford

Nuclear Safety:

Robert G. Morgan

Manager

DE\&S Hanford

MCO Design Authority:

L. H. Goldmann

DE\&S Hanford
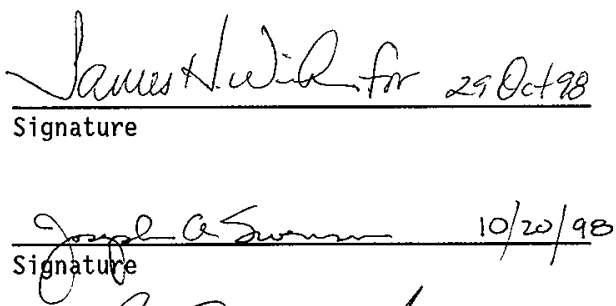

silgnature

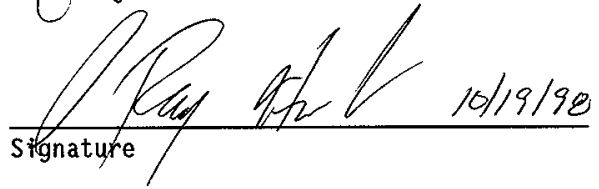


HNF-3420, Rev. 0

\title{
MULTI-CANISTER OVERPACK
}

\author{
INTERNAL HEPA FILTERS
}

\section{Introduction}

The Multi-Canister Overpack (MCO) design includes a bank of HEPA filter elements installed inside the vessel to prevent outflow of radiologically contaminated gas during the Cold Vacuum Drying (CVD) process and during any future sampling/processing activities. The rationale for locating a filter assembly inside each MCO rather than include the filter in the CVD process piping system was to eliminate the potential for contamination to the operators, processing equipment, and the outside of the MCO. Due to concerns regarding potential filter plugging and extended drying times should the filters get wet, suggestions have been made to relocate the filters from the MCO to the CVD process equipment piping, resulting in a potential cost savings to the project. The purpose of this paper is to summarize the assessments that have been completed addressing the feasibility of removing the HEPA filters internal to the MCO and replacing them with filters in the CVD process piping system.

\section{Discussion}

With the adoption of the MCO Sealing Strategy and deletion of both the Hot Conditioning process and the staging activity at the Canister Storage Building (CSB), the functions performed by the MCO filters were reduced. Reference 1 is a white paper prepared in the fall of 1997 which reviewed the merits of deleting the MCO filters based on this reduction in functions performed. This review concluded that actions necessary to implement an alternative filtering approach could offset potential cost savings, present contamination control challenges, and threaten the start of fuel movement. An excerpt from the assessment follows:

"For CVD process operation deletion of the filter has implications on operations. Risk of contamination, especially alpha contamination in the connectors of the CVD process system to the $\mathrm{MCO}$ and downstream in the gas flow piping will be increased. Smearable contamination levels within the MCO after drying will be orders of magnitude above those that require special operational controls for alpha contamination. Further, this form of contamination is prone to airborne transmission mechanisms. Discussion with operations and safety personnel familiar with these materials and operations confirms that the filter is essential to disconnecting the gas effluent line safely and efficiently. Input on this question has been received from Basin operations staff and 
management, start up management, and K-Basin safety staff and management, and technical staff familiar with French fuel hand1ing activities. In addition, informal confirming opinion was received from site technical staff familiar with PUREX and other Hanford 200 area operations."

"Direct experience with K-Basin materials supports justification of the need for the filter. Excessive agitation of $K$ East Basin water results in the facility going on mask for alpha. Also at the 300 area laboratory while drying a sample weighing only a few grams in the small furnace a leaking filter in the process piping resulted in a contamination event that contaminated personne], shut down the facility, and drove revision to the contamination control design for the laboratory equipment."

"Alternatives to the use of the filters internal to the MCO such as sealing the MCO for transfer to CVD and installing a filter in the CVD process piping have been identified. However, no alternative has been identified that deals effectively with the need to control contamination while breaking the process piping connections."

To obtain an independent assessment of this issue, the ALARA Center of Technology was requested to review the MCO and CVD designs to determine whether the MCO filters could be removed. Their assessement (Reference 2) concluded that removal of the filters would place plant operators at risk for external and internal contamination.

"The HEPA provides for contamination control of the MCO exterior surface and surrounding areas when the process valve operators are disconnected from the MCO Shield Plug. This is one of the two (HVAC being the other) primary contamination control features protecting operators from skin contamination and possible internal depositions while handiing the valve operators. The internal HEPAs will also allow the operators to perform their task without requiring respirator protection as required by 10 CFR $835.1002(c)$. We feel that removal of the internal HEPAs will place the plant operators at a risk from external and internal contamination."

"Secondly, the internal HEPAs are needed to ensure the processing equipment at the CVDF is maintained as clean as possible. By minimizing the contamination of process equipment the overa 71 background radiation in the process bays will be reduced. Installing a HEPA filter in the CVDF processing system to replace the internal HEPA filter will increase radiological control requirements for all remaining work due to higher background radiation. This would be in conflict with the ALARA requirements of 10 CFR 835.1001 a."

"If a filter were not installed on the shield plug, another HEPA filter would have to be installed in the CVDF processing equipment to prevent the processing equipment from getting contaminated. This filter would probably become highly contaminated after several MCOs are vented and 
HNF-3420, Rev. 0

require temporary shielding to be installed to reduce dose rates from the filter housings. The filter would probably require replacement frequently which would result in extra dose to the workers as well as increase the risk of contamination spread."

Recently completed testing of the CVD process at the 306 Building has demonstrated that MCO draining and drying can be completed within the scheduled duration and that the filters do not add measurable time to the drying operation. Concern regarding wetting of the filters has been addressed with both the shield plug and filter designs. First, the filter elements are housed in stainless steel cylinders with gas inlet holes in the upper portion of the end cap. Any sloshing of water during MCO transport will not wet the filter media. Second, the filter guard plate welded to the shield plug underside provides a "diving bell" effect during underwater shield plug installation. The guard $\mathrm{plate}$ and ring form a pocket of air around the filter assembly, effectively keeping water from contacting the filters. These two measure will ensure that the filters remain dry in preparation for CVD operations.

\section{Conclusion}

The internal HEPA filters provide essential protection to facility workers from alpha contamination, both external skin contamination and potential internal depositions. Filters installed in the CVD process piping cannot mitigate potential contamination when breaking the process piping connections. Experience with K-Basin material has shown that even an extremely small release can result in personnel contamination and costly schedule distruptions to perform equipment and facility decontamination. Incorporating the filter function internal to the MCO rather than external is consistent with ALARA requirements of 10 CFR 835 . Based on the above, the SNF Project position is to retain the internal HEPA filters in the MCO design.

\section{$\underline{\text { References }}$}

1. DESH white paper prepared by J.A. Swenson, informally transmitted to P.G. Loscoe, fal1 1997; copy located in MCO Project files

2. Internal Memo, L. Waggoner, ALARA Center of Technology, to C.A. Thompson, SNF Project, "Assessment of whether a HEPA Filter should be Installed in the Multi-Canister Overpack (MCO) Shield Plug", dated September 16, 1998. 


\section{DISTRIBUTION COVERSHEET}

Subject: MCO ISSUE PAPERS PER ATTACHED DISTRIBUTION INDEX

\section{DISTRIBUTION}

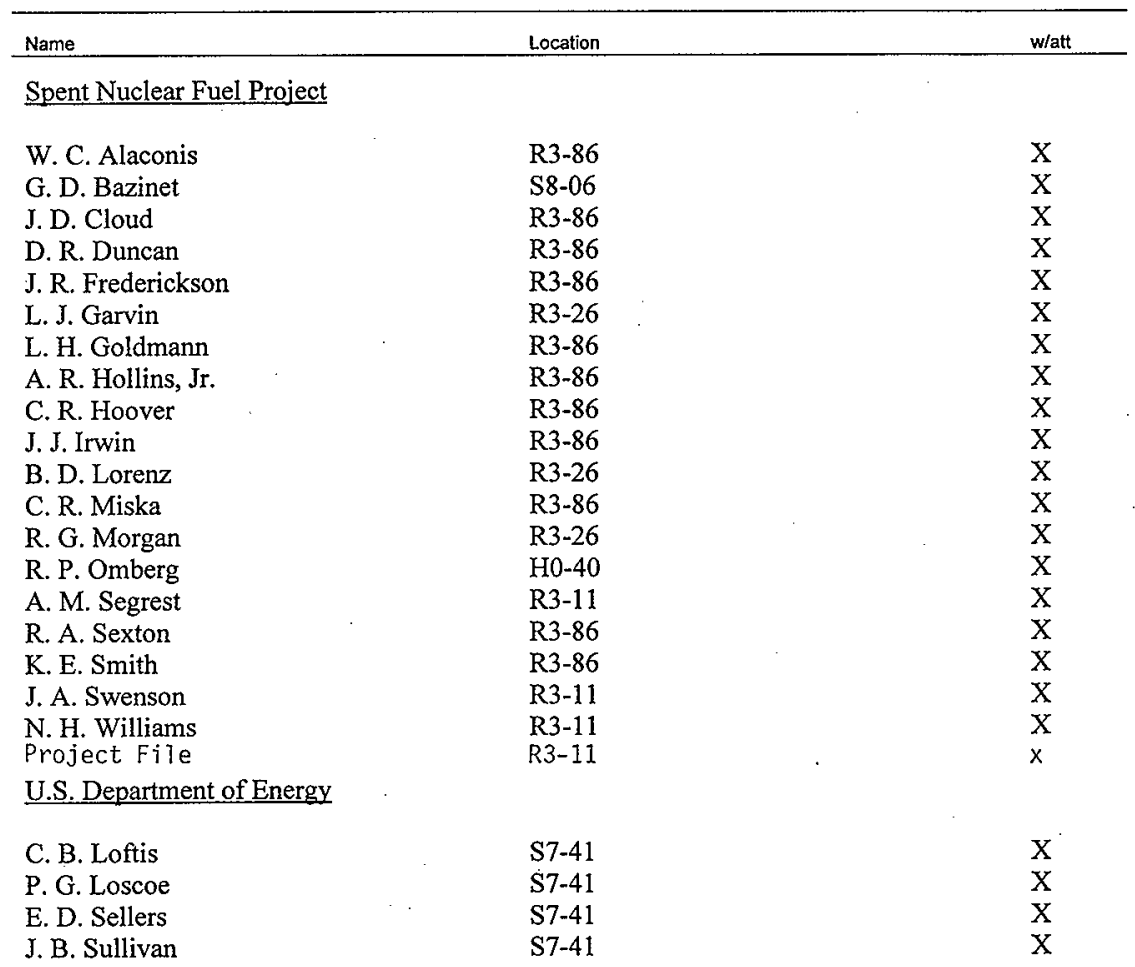




\section{DISTRIBUTION INDEX}

The Multi-Canister Overpack Issue papers listed below are being distributed as a package to facilitate future reference and use by SNF Project personnel. The following issue papers are attached:

1. HNF-2876, Oxygen Gettering Issue Closure Package

2. HNF-3265, MCO Number of Shield Plug Ports

3. HNF-3399, MCO Necessity of the Rupture Disk

4. HNF-3267, MCO Dual Pressure Rating

5. HNF-3293, MCO Ultrasonic Examination of Closure Weld

6. HNF-3354, MCO Monitoring Issue Closure Package and HNF-3312, MCO Monitoring Activity Description

7. HNF-3292, MCO Sealing Configuration

8. HNF-3266, MCO Design Pressure Rating

9. HNF-3255, ASME Code Requirements for MCO Design and Fabrication

10. HNF-3398, MCO Inservice Inspection and Maintenance

11. HNF-3420, MCO Internal HEPA Filters

12. HNF-3036, Low Reactive Surface Area Issue Closure Package

13. HNF-3270, MCO Pressure Testing 